\title{
A novel approach to understanding the role of polymorphic forms of the NR3C1 and TGF- $\beta 1$ genes in the modulation of the expression of IL-5 and IL-15 mRNA in asthmatic inflammation
}

\author{
MICHAŁ PANEK ${ }^{1}$, MATEUSZ JONAKOWSKI ${ }^{2}$, JAN ZIOŁO $^{2}$, ŁUKASZ WIETESKA $^{3}$, \\ BEATA MAŁACHOWSKA ${ }^{4}$, TADEUSZ PIETRAS ${ }^{5}$, JANUSZ SZEMRAJ ${ }^{6}$ and PIOTR KUNA ${ }^{1}$ \\ ${ }^{1}$ Department of Internal Medicine, Asthma and Allergy; ${ }^{2}$ Students Research Group, \\ The Department of Internal Medicine, Asthma and Allergy, Medical University of Lodz, Lodz 90-153; \\ ${ }^{3}$ Department of Medical Biochemistry, Medical University of Lodz, Lodz 92-215; ${ }^{4}$ Department of Pediatrics, Oncology, \\ Hematology and Diabetology of Medical University of Lodz, Lodz 91-738; 5 Department of Pneumology and Allergology, \\ Medical University of Lodz, Lodz 90-153; ${ }^{6}$ Department of Medical Biochemistry, \\ Medical University of Lodz, Lodz 92-215, Poland
}

Received November 2, 2015; Accepted January 13, 2016

DOI: $10.3892 / \mathrm{mmr} .2016 .5104$

\begin{abstract}
The aim of the present study was to identify polymorphic forms of the nuclear receptor subfamily 3 , group $\mathrm{C}$, member $1(\mathrm{NR} 3 \mathrm{Cl})$ and transforming growth factor $\beta 1$ (TGF- $\beta 1$ ) genes and evaluate their impact on the expression levels of interleukin (IL)-5 and IL-15 in asthma. The study was conducted on a control group consisting of 91 people (54 women and 37 men). The patient group consisted of 130 participants (86 women and 44 men). Genotyping was performed by polymerase chain reaction-restriction fragment length polymorphism (PCR-RFLP) and PCR-high resolution melting (HRM) methods. Interleukin expression was measured by reverse transcription-quantitative polymerase chain reaction. The frequency of the polymorphic forms in the analyzed group were observed to be: Tth111I (rs10052957) controls AA 0.0440 , AG 0.5714, GG 0.3846, patients AA 0.1538/AG 0.4692, GG 0.3769; ER22/23EK (rs6189 /rs6190) controls AG 0.0556, GG 0.9444, patients AG 0.0385, GG 0.9615; N363S (rs6195) controls AA 0.6444, AG 0.2667, GG 0.0889, patients AA 0.7846, AG 0.1385, GG 0.0769; BclI (rs41423247) controls CC 0.0879, CG 0.5604, GG 0.3516, patients CC 0.1008, CG 0.5736, GG 0.3256; C-509T (rs1800469) controls TT 0.0805, CT 0.6322, CC 0.2874, patients TT 0.1102, CT 0.5669, CC 0.3228 . The results indicated that the $\mathrm{C}-509 \mathrm{~T}$ single nucleotide polymorphism (SNP) of the TGF- $\beta 1$ gene contributed to an increase in the IL-5 mRNA expression levels. The GG genotype
\end{abstract}

Correspondence to: Dr Michał Panek, Department of Internal Medicine, Asthma and Allergy, Medical University of Lodz, 22 Kopcinskiego Street, Lodz 90-153, Poland

E-mail: michalmp@poczta.onet.pl

Key words: NR3C1 gene, TGF- $\beta 1$ gene, IL-5 expression, IL-15 expression, inflammation, asthma of the N363S SNP of the NR3C1 gene was observed to result in an increase in the expression levels of IL-15. The present study indicated that the selected SNPs of the NR3C1 and TGF- $\beta 1$ genes demonstrate a regulatory effect on the expression of IL-5 and IL-15. Therefore, genetic variation affects inflammation in asthma and the clinical course of the disease.

\section{Introduction}

Asthma is a heterogenous disorder, characterized by chronic inflammation of the respiratory tract. Numerous genes and their polymorphic forms are involved in the pathogenesis of this disease. It is estimated that $35-70 \%$ of cases of asthma and allergy are genetically conditioned $(1,2)$. The following genes serve a particularly important role in the pathophysiological mechanisms of allergic diseases and asthma: Growth factors [e.g. transforming growth factor- $\beta$, (TGF- $\beta)$ ], cytokines regulating immunological processes [interleukins, e.g. interleukin (IL)-5, IL-15] and those which condition a positive response to glucocorticosteroid (GC) therapy [nuclear receptor subfamily 3 , group C, member 1 (NR3C1)] (2-7).

The NR3Cl gene is located on the long arm of chromosome 5 (5q31-q32) and encodes the GC receptor (GR). The GR consists of 5 structural domains (A/B, C, D, E and F), which exhibit biological function: Activation function 1 (AF1); DNA-binding domain (DBD); nuclear localization sequence (NLS); ligand binding domain (LBD); and AF2. The occurrence of polymorphisms in the NR3C1 gene modifies the activity of the gene regulatory parts, which affects the function of the promoter and coded protein (8-11). Tth111I (rs10052957), ER22/23EK (rs6189/rs6190), N363S (rs6195) and BclI (rs41423247) single nucleotide polymorphisms (SNPs) of the $N R 3 C 1$ gene increase the risk of asthma, affect the clinical course of the disease and condition the response to $\mathrm{GC}$ anti-inflammatory treatment (level of asthma control, steroid dependence or steroid resistance) (12-15). Following the binding of the GC ligand, the GR becomes an active transcription 
factor, which inhibits the expression (transrepression) of certain genes, such as IL-5 (2,16-19). In the transactivation mechanism, an increased production of anti-inflammatory proteins is observed. In addition, GCs increase the production and release of IL-15 $(2,20)$.

IL-5 is produced by activated $\mathrm{T}$ lymphocytes and macrophages, and in asthma promotes the differentiation, migration and activation of eosinophils, and prolongs their survival in sites of allergic inflammation. The occurrence of IL-5 manifests with bronchial hyperreactivity, clinical symptoms and bronchial obstruction, as a result of inflammatory mediators released from eosinophils, such as leukotrien C4) (21-24).

IL-15 serves a vital role in the maturation of natural killer (NK) cells. It stimulates antibody-dependent cytotoxicity, differentiates monocytes to dendritic cells with a Langerhans cell phenotype, stimulates $\mathrm{T}$ lymphocyte proliferation and migration, and regulates inflammatory responses to the production of cytokines and chemokines $(20,25,26)$. In a comparison of a group of patients with asthma treated with GCs with a control group, it was indicated that the sputum of the patients with asthma contained higher levels of IL-15, which suggests a significant role of this interleukin in the regulation of immune and inflammatory responses in asthma $(20,26)$.

There are three different human isoforms of TGF- $\beta$, which are located in the following chromosomal loci: TGF- $\beta 1-19 q 13$, TGF- $\beta 2-1 q 41$ and TGF- $\beta 3-14 q 24$ (27-29). Asthma is associated with elevated levels of TGF- $\beta 1$ and TGF- $\beta 2$. TGF- $\beta 1$ is expressed on the vascular endothelium, and in smooth muscles, fibroblasts and platelets. It regulates the growth of eosinophils and lymphocytes in response to exposure to allergens. TGF- $\beta$ promotes the growth of smooth muscle, subepithelial fibrosis, increases production of the extracellular matrix and promotes fibroblast activation. In addition, it regulates allergic inflammation in asthma and affects airway remodeling (30-32). TGF- $\beta$ induces IL-5 in the proapoptotic cosignaling mechanism $(33,34)$. It leads to the suppression of activated peripheral blood eosinophils and tissue eosinophils via the inhibition of Lyn kinase, mitogen-activated protein kinase (MAPK), Janus kinase 2 and signal transducer and activator of transcription 1 nuclear factor (33-39). TGF- $\beta$ regulates IL-15 expression, with TGF- $\beta$ observed to increase the expression levels of IL-15. In a previous study, following the application of siRNA, mothers against decapentaplegic (Drosophila) and SMA (Caenorhabditis elegans) homolog $3(\operatorname{Smad} 3)$, however, not Smad2 was observed to be involved in the induction of IL-15 mRNA induction by TGF- $\beta$ (40). In addition to the Smad2/3 pathway, TGF- $\beta$ activated numerous kinases, MAPK and c-Jun N-terminal kinase, and the phosphoinositide 3-kinase-protein kinase B signaling pathway (40). However, one report indicated that TGF- $\beta 1$ inhibits the production of IL-15 (41). SNPs in the TGF- $\beta 1$ gene including C-509T (rs1800469), C+466T (rs200482214) and T+869C (rs1800470) influence the expression levels of TGF- $\beta 1$ and immunoglobulin $\mathrm{E}$ ( $\operatorname{IgE})$, bronchial remodeling, the risk of asthma and its clinical control (42-48).

The aim of the present study was to identify polymorphic forms of the NR3Cl and TGF- $\beta 1$ genes and evaluate their effect on the expression levels of IL-5 and IL-15 in asthma.

\section{Materials and methods}

Study participants. The current study was approved by the local ethics committee (Consent of Research Review Board, Medical University of Lodz, Poland, No RNN/133/09/KE). Study participants were volunteers and written informed consent was obtained from every patient prior to enrolment in the study.

Asthma diagnosis was established according to the Global Initiative For Asthma (GINA) recommendations (www.ginasthma.org), based on clinical asthma symptoms and a lung function test. The level of asthma severity and control was determined on the basis of GINA Report Guidelines. The patients medical history, including gender, obesity, tobacco smoking, duration of bronchial asthma, allergy to house dust mites, animal fur, mould spores, cockroach allergens, hypersensitivity to non-steroidal anti-inflammatory drugs was collected, in addition to objective examinations (spirometry tests). The results of pulmonary function tests and allergological tests were obtained from the individual medical records of the patients. If no spirometry or allergological test results were available, such examinations were performed during the recruitment visit. Subjects demonstrating clinically significant exacerbations, using drugs that may induce resistance to glucocorticoids (e.g. rifampicin, phenobarbital, phenytoin and effedrine), subjects with signs of viral infections (either generalized or affecting the respiratory tract), in addition to subjects failing to comply with the doctor's recommendations, were excluded from the patient group. The control group consisted of healthy adults, who met the following criteria: No history or symptoms of either bronchial asthma or other pulmonary diseases, no history or symptoms of allergy, no history or symptoms of atopic dermatitis, no history or symptoms of hypersensitivity to aspirin, negative results of skin tests for 12 common allergens and no first-degree relatives with bronchial asthma or atopic disorders. Spirometry tests were conducted in the Specialist Outpatient Clinic of Pulmonary Diseases and Allergology of the Norbert Barlicki University Clinical Hospital (Lodz, Poland) according to European Respiratory Society/American Thoracic Society standards (49), and allergological tests according to the guidelines of the European Academy of Allergy and Clinical Immunology $(7,13,15,28)$.

The study was conducted on 221 participants. The control group consisted of 91 people [54 women $(59.34 \%)$ and 37 men (40.66\%)], with an age range of 21-80 years old. The mean age in the control group was $46.96 \pm 16.42$ years, with a median of 48.00 years. The patient group consisted of 130 participants [86 women (66.15\%) and 44 men (33.85\%)], with an age range of $22-78$ years old. The mean age in the patient group was $50.24 \pm 14.55$ years, with a median of 52.00 years. Non-severe asthma was diagnosed in 75 patients $(57.69 \%)$, whereas 55 patients $(42.31 \%)$ had a severe form of the disease. Comprehensive comparison of spirometric parameters of the analyzed groups is presented in Table I.

The study participants were stratified and subjected to statistical analysis. The genotyping was performed by two blinded investigators.

SNP analysis. Venous blood samples were collected from the participants into tripotassium ethylenediaminetetraacetic acid 
Table I. Spirometric parameters of the analyzed groups.

\begin{tabular}{|c|c|c|}
\hline Parameter & Controls & Patients \\
\hline \multicolumn{3}{|l|}{ FEV1 (1) } \\
\hline Mean & 2.99 & 2.15 \\
\hline Median & 2.97 & 1.98 \\
\hline Min & 1.40 & 0.37 \\
\hline Max & 5.24 & 4.68 \\
\hline SD & 0.82 & 0.90 \\
\hline \multicolumn{3}{|l|}{ FEV1 (\%) } \\
\hline Mean & 96.17 & 72.48 \\
\hline Median & 95.00 & 73 \\
\hline Min & 66.00 & 19 \\
\hline Max & 128.00 & 125 \\
\hline $\mathrm{SD}$ & 11.67 & 21.27 \\
\hline \multicolumn{3}{|l|}{ FVC (1) } \\
\hline Mean & 3.77 & 3.15 \\
\hline Median & 3.55 & 2.91 \\
\hline Min & 1.87 & 1.11 \\
\hline Max & 6.37 & 6.52 \\
\hline SD & 1.04 & 1.08 \\
\hline \multicolumn{3}{|l|}{$\mathrm{FVC}(\%)$} \\
\hline Mean & 101.52 & 89.77 \\
\hline Median & 101.00 & 89.00 \\
\hline Min & 71.00 & 38.00 \\
\hline $\operatorname{Max}$ & 150.00 & 134 \\
\hline $\mathrm{SD}$ & 13.49 & 18.40 \\
\hline \multicolumn{3}{|c|}{ FEV1\%FVC } \\
\hline Mean & 79.49 & 67.19 \\
\hline Median & 78.00 & 67.95 \\
\hline Min & 64.15 & 33.33 \\
\hline Max & 95.15 & 91.03 \\
\hline $\mathrm{SD}$ & 6.28 & 12.32 \\
\hline
\end{tabular}

FEV1 (L), forced expiratory volume in $1 \mathrm{sec}$, expressed in litres; Min, minimum; Max, maximum; SD, standard devation; FEV1\%, percentage ratio of the measured to expected value, expressed as percentage of the expected value; FVC, forced vital capacity, expressed in litres; $\mathrm{FVC} \%$, percentage ratio of the measured to expected value, expressed as percentage of the expected value; FEV1\%FVC, FEV1 to FVC ratio of forced vital capacity, expressed as absolute numbers.

tubes (Sarstedt AG \& Co., Nümbrecht, Germany). DNA was obtained from the peripheral blood leukocyte fraction. The genetic material was isolated using a QIAamp DNA Blood Mini kit (Qiagen GmbH, Hilden, Germany) according to the manufacturer's instructions. The investigated polymorphisms were analyzed using polymerase chain reaction-restriction fragment length polymorphism (PCR-RFLP) and PCR-high resolution melting (HRM) methods, as described previously $(13,50-53)$. Table II presents a description of the applied genotyping techniques.

Reverse transcription-quantitative polymerase chain reaction (RT-qPCR). A total of $10 \mu \mathrm{g}$ total RNA was extracted from the peripheral blood lymphocytes using an RNA extraction reagent, (TRI Reagent ${ }^{\circledR}$ Solution; Ambion; Thermo Fisher Scientific, Inc., Waltham, MA, USA), according to the standard of the acid guanidinium phenol-chloroform method (54). The extracted RNA was analyzed by agarose gel $(8 \%)$ electrophoresis and only cases with preserved $28 \mathrm{~S}$, $18 \mathrm{~S}$ and $5 \mathrm{~S}$ ribosomal RNA bands indicating good RNA quality were used in the study. Total RNA was digested with DNase (Gibco; Thermo Fisher Scientific, Inc.) at room temperature for $15 \mathrm{~min}$. The amount of purified RNA was determined using spectrophotometry at $260 \mathrm{~nm}$ in a Nanodrop ND-100 analyser (Nanodrop; Thermo Fisher Scientific, Inc., Wilmington, DE, USA). The purity was verified according to the ratio of 260/280 nm measurements; values between 1.8 and 2.1 indicated that the quality of the obtained RNA was optimal and suitable for RT-qPCR $(7,28,54)$. Reverse transcription of $1 \mu \mathrm{g}$ RNA was performed using an AccuScript PfuUltra II RT-PCR kit (Agilent Technologies, Santa Clara, CA, USA). The cDNA was subjected to qPCR using gene specific primers for IL-5, IL-15 and GAPDH using EvaGreen ${ }^{\circledR}$ Master Mix for RT-qPCR (Biotium, Inc., San Francisco CA, USA) and Phusion ${ }^{\circledR}$ High-Fidelity DNA Polymerase (Thermo Fisher Scientific, Inc.). Table III presents the primer sequences used for RT-qPCR. An Agilent Mx3000P qPCR system (Agilent Technologies, Inc., Santa Clara, CA, USA) was used for the IL-5 and IL-15 RT-qPCR reaction. Bands were visualized using ImageMaster (Pfizer, New York City, NY, USA). For each sample, the CQ (quantification cycle) values were calculated using Mx-Pro software (Agilent Technologies, Inc.). The RT-qPCR amplification of the IL-5 and IL-15 genes was compared with the levels of glyceraldehyde 3-phosphate dehydrogenase (GAPDH), a house-keeping reference gene, and the $\triangle \mathrm{CQ}$ values were determined $\left(\Delta \mathrm{C}_{\mathrm{Q}}=\mathrm{C}_{\mathrm{Q}, \mathrm{GENE}}-\mathrm{C}_{\mathrm{Q}}\right.$, GAPDH). The RT-qPCR data was automatically calculated with the data analysis module. The results were analyzed with the application of the $2^{-\Delta \Delta C T}$ method. Validation of PCR efficiency was performed with a standard curve $(7,28,54-56)$.

Statistical analysis. Nominal variables are presented as percentages, and continuous variables are presented as the mean \pm standard deviation or the median and the interquartile range (IQR). The Yate's chi-square test and Fisher-Freeman-Halton exact test were used to test the associations. The continuous variables were analyzed using the Mann-Whitney U test or analysis of variance depending on the number of groups being compared. Correlation coefficients were calculated using the Spearman's rank correlation. To test whether the genotype frequencies of the SNPs were consistent with the Hardy-Weinberg equilibrium, Michael H. Court's online calculator was used: http://www. tufts.edu/ mcourt01/Documents/Court\%20lab\%20-\%20 HW\%20calculator.xls. $\mathrm{P}<0.05$ was considered to indicate a statistically significant difference. Statistica software, version 10.0 (Statsoft, Inc., Tulsa, OK, USA) was used for statistical analysis.

\section{Results}

Different IL-5 mRNA expression levels were observed in the control and patient groups, with a median of 1.46 (patients) 
Table II. Parameters of PCR reactions, used for genotyping of SNPs of the NR3C1 and TGF- $\beta 1$ genes.

\begin{tabular}{|c|c|c|c|c|}
\hline Gene & SNP & $\begin{array}{l}\text { PCR } \\
\text { technique }\end{array}$ & Primers & $\begin{array}{l}\text { Primer annealing } \\
\text { temperature }\end{array}$ \\
\hline$N R 3 C 1$ & $\begin{array}{c}\text { Tth111I } \\
\text { (rs10052957) }\end{array}$ & HRM & $\begin{array}{l}\text { Forward 5'-GCAGAGGTGGAAATGAAGGTG-3' } \\
\text { Reverse 5'-GGAGTGGGACATAAAGCTATGACA-3' }\end{array}$ & $58^{\circ} \mathrm{C}$ \\
\hline$N R 3 C 1$ & $\begin{array}{c}\text { ER22/23EK } \\
\text { (rs6189/rs6190) }\end{array}$ & RFLP $M n l I$ & $\begin{array}{l}\text { Forward 5'-TGCATTCGGAGTTAACTAAAAAG-3' } \\
\text { Reverse 5'-ATCCCAGGTCATTTCCCATC-3' }\end{array}$ & $56^{\circ} \mathrm{C}$ \\
\hline$N R 3 C 1$ & $\begin{array}{l}\mathrm{N} 363 \mathrm{~S} \\
(\mathrm{rs} 6195)\end{array}$ & $\begin{array}{l}\text { RFLP Tsp509I } \\
\quad(\text { Tas I) }\end{array}$ & $\begin{array}{l}\text { Forward 5'-CCAGTAATGTAACACTGCCCC-3' } \\
\text { Reverse 5'-TTCGACCAGGGGAAGTTCAGA-3' }\end{array}$ & $56^{\circ} \mathrm{C}$ \\
\hline$N R 3 C 1$ & $\begin{array}{c}B c l I \\
(\text { rs41423247) }\end{array}$ & RFLP $B c l I$ & $\begin{array}{l}\text { Forward 5'-GAGAAATTCACCCCTACCAAC-3' } \\
\text { Reverse 5'-AGAGCCCTATTCTTCAAACTG-3' }\end{array}$ & $56^{\circ} \mathrm{C}$ \\
\hline TGF- $\beta 1$ & $\begin{array}{c}\mathrm{C}-509 \mathrm{~T} \\
(\mathrm{rs} 1800469)\end{array}$ & HRM & $\begin{array}{l}\text { Forward 5'-GTGTCTGCCTCCTGACCCTCC-3' } \\
\text { Reverse 5'-GCCTCCGGAGGGTGTCAGTG-3' }\end{array}$ & $62^{\circ} \mathrm{C}$ \\
\hline TGF- $\beta 1$ & $\begin{array}{c}\mathrm{C}+466 \mathrm{~T} \\
(\mathrm{rs} 200482214)\end{array}$ & HRM & $\begin{array}{l}\text { Forward 5'-CATGTCCTCACCTGGTACAGC-3' } \\
\text { Reverse 5'-CCTGAACCCGTGTTGCTCTC-3' }\end{array}$ & $64^{\circ} \mathrm{C}$ \\
\hline TGF- $\beta 1$ & $\begin{array}{c}\mathrm{T}+869 \mathrm{C} \\
(\mathrm{rs} 1800470)\end{array}$ & HRM & $\begin{array}{l}\text { Forward 5'-CTGTTCGCGCTCTCGGCAG-3' } \\
\text { Reverse 5'- CCAGTAGCCACAGCAGCGG-3' }\end{array}$ & $68^{\circ} \mathrm{C}$ \\
\hline
\end{tabular}

PCR, polymerase chain reaction; SNPs, single nucleotide polymorphisms; NR3C1, nuclear receptor subfamily 3, group C, member 1; TGF- $\beta 1$, transforming growth factor $\beta 1$; HRM, high resolution melting; RFLP, restriction fragment length polymorphism.

Table III. Primer sequences used for reverse transcription-quantitative polymerase chain reaction to measure the mRNA expression of IL-5 and IL-15.

Gene Primers

Primer annealing temperature

\begin{tabular}{ll}
\hline IL-5 & Forward 5'-CCTTGCACAGTTTGACTCTC-3' \\
& Reverse 5'-GAGGATTCCTGTTCCTGTAC-3' \\
IL-15 & Forward 5'-GTGTTGATGAACATTTGCAC-3' \\
& Reverse 5'-AAGTTATTTCACTTGACTCCG-3' \\
GAPDH & Forward 5'-AGCCACATCGCTCAGACA-3' \\
& Reverse 5'-GCCCAATACGACCAAATCC-3' \\
\hline
\end{tabular}

IL, interleukin.

(IQR, 0.16-5.34) compared with 0.18 (controls) (IQR, 0.32-1.66; $\mathrm{P}<0.001)$. In addition, the IL-15 mRNA expression levels in the patient and control groups were significantly different, with a median of 0.60 (patients) (IQR, 0.25-1.09) compared with 0.27 (controls) (IQR, 0.04-0.75; P<0.01).

It was observed that no SNPs of the NR3Cl gene significantly correlated with the altered levels of IL-5, in which the highest levels of IL-5 mRNA expression were observed (Fig. 1). In the $N R 3 C 1$ gene, the most common polymorphism observed in Tth111I was the AG genotype (69.23\% controls, $62.00 \%$ asthmatic patients), in ER22/23EK was the GG genotype $(94.74 \%$ controls, $97.96 \%$ asthmatic patients), in N363S was the AA genotype (78.95\% controls, $82.00 \%$ asthmatic patients) and in $B c l$ I was the CG genotype (48.72\% controls, $61.22 \%$ asthmatic patients). Notably, the AA polymorphic form was not observed for ER22/23EK.
In the TGF- $\beta 1$ gene, three C-509T polymorphic forms (TT, CT and CC) were observed, with the most common genotype being CT (66.67\% controls, $61.22 \%$ asthmatic patients). The risk factor contributing to an increase in IL-5 mRNA expression was TT in the C-509T SNP of the TGF- $\beta 1$ gene ( $10.26 \%$ controls, $8.16 \%$ asthmatic patients). Expression of the TT allele increased the risk of higher IL-5 mRNA expression by $44 \%$ in the group of asthmatic patients. The polymorphic forms of the TGF- $\beta 1$ gene, $\mathrm{C}+466 \mathrm{~T}$ and $\mathrm{T}+869 \mathrm{C}$, occurred only in one genotype form, TT (100\%), both in the control group and in patients with asthma. However, these polymorphisms did not affect the expression levels of IL-5 mRNA in patients with asthma (Table IV).

It was observed that only one of the four NR3C1 SNPs was significantly associated with the altered IL-15 mRNA expression levels (Fig. 2). The N363S SNP occurred in three 
Table IV. Frequency of polymorphic forms of NR3C1 and TGF- $\beta 1$ SNPs and the effect on IL-5 mRNA expression levels.

\begin{tabular}{|c|c|c|c|c|c|c|c|}
\hline \multirow[b]{2}{*}{ SNP } & \multirow[b]{2}{*}{ Polymorphism } & \multicolumn{2}{|c|}{ Controls } & \multicolumn{2}{|c|}{ Patients } & \multirow[b]{2}{*}{ OR } & \multirow[b]{2}{*}{$95 \% \mathrm{CI}$} \\
\hline & & Frequency & $\begin{array}{l}\text { IL-5 mRNA } \\
\text { expression }\end{array}$ & Frequency & $\begin{array}{l}\text { IL-5 mRNA } \\
\text { expression }\end{array}$ & & \\
\hline \multirow{3}{*}{$\begin{array}{l}\text { Tth111I } \\
\text { (rs10052957) }\end{array}$} & AA & $0.0513,5.13 \%$ & $2.08 \pm 0.83$ & $0.0600,6.00 \%$ & $1.29 \pm 2.08$ & - & - \\
\hline & $\mathrm{AG}$ & $0.6923,69.23 \%$ & $1.31 \pm 1.18$ & $0.6200,62.00 \%$ & $1.56 \pm 1.42$ & 1.10 & $0.81-1.39$ \\
\hline & GG & $0.2564,25.64 \%$ & $2.11 \pm 1.78$ & $0.3200,32.00 \%$ & $1.19 \pm 1.22$ & 0.94 & $0.64-1.23$ \\
\hline \multirow{3}{*}{$\begin{array}{l}\text { ER22/23EK } \\
\text { (rs6189/rs6190) }\end{array}$} & $\mathrm{AA}$ & $0.0000,0 \%$ & - & $0.0000,0 \%$ & - & - & - \\
\hline & $\mathrm{AG}$ & $0.0526,5.26 \%$ & $2.39 \pm 3.09$ & $0.0204,2.04 \%$ & $4.03 \pm 0.0$ & - & - \\
\hline & GG & $0.9474,94.74 \%$ & $1.51 \pm 1.31$ & $0.9796,97.96 \%$ & $1.36 \pm 1.35$ & 0.76 & $0.49-1.04$ \\
\hline \multirow{3}{*}{$\begin{array}{l}\text { N363S } \\
\text { (rs6195) }\end{array}$} & $\mathrm{AA}$ & $0.7895,78.95 \%$ & $1.63 \pm 1.47$ & $0.8200,82.00 \%$ & $1.49 \pm 1.47$ & 1.10 & $0.70-1.51$ \\
\hline & $\mathrm{AG}$ & $0.2105,21.05 \%$ & $1.26 \pm 1.01$ & $0.1400,14.00 \%$ & $1.10 \pm 0.92$ & - & - \\
\hline & GG & $0.0000,0 \%$ & - & $0.0400,4.00 \%$ & $1.30 \pm 0.79$ & 1.00 & $0.59-1.41$ \\
\hline \multirow{3}{*}{$\begin{array}{l}B c l I \\
\text { (rs41423247) }\end{array}$} & $\mathrm{CC}$ & $0.1538,15.38 \%$ & $1.02 \pm 1.61$ & $0.1020,10.20 \%$ & $1.20 \pm 0.78$ & - & - \\
\hline & $\mathrm{CG}$ & $0.4872,48.72 \%$ & $1.74 \pm 1.59$ & $0.6122,61.22 \%$ & $1.50 \pm 1.56$ & 1.11 & $0.83-1.40$ \\
\hline & GG & $0.3590,35.90 \%$ & $1.53 \pm 0.86$ & $0.2857,28.57 \%$ & $1.16 \pm 0.93$ & 0.94 & $0.66-1.23$ \\
\hline \multirow{3}{*}{$\begin{array}{l}\text { C-509T } \\
\text { (rs1800469) }\end{array}$} & $\mathrm{TT}$ & $0.1025,10.26 \%$ & $2.30 \pm 0.84$ & $0.0816,8.16 \%$ & $2.54 \pm 1.38$ & 1.44 & $1.05-1.83$ \\
\hline & $\mathrm{CT}$ & $0.6667,66.67 \%$ & $1.35 \pm 0.93$ & $0.6122,61.22 \%$ & $1.54 \pm 1.28$ & 0.90 & $0.51-1.30$ \\
\hline & $\mathrm{CC}$ & $0.2308,23.08 \%$ & $1.81 \pm 2.32$ & $0.3061,30.61 \%$ & $0.99 \pm 1.45$ & - & - \\
\hline
\end{tabular}

$N R 3 C 1$, nuclear receptor subfamily 3 , group C, member 1 ; TGF- $\beta 1$, transforming growth factor $\beta 1$; SNPs, single nucleotide polymorphisms; IL, interleukin; OR, odds ratio; CI, confidence interval.
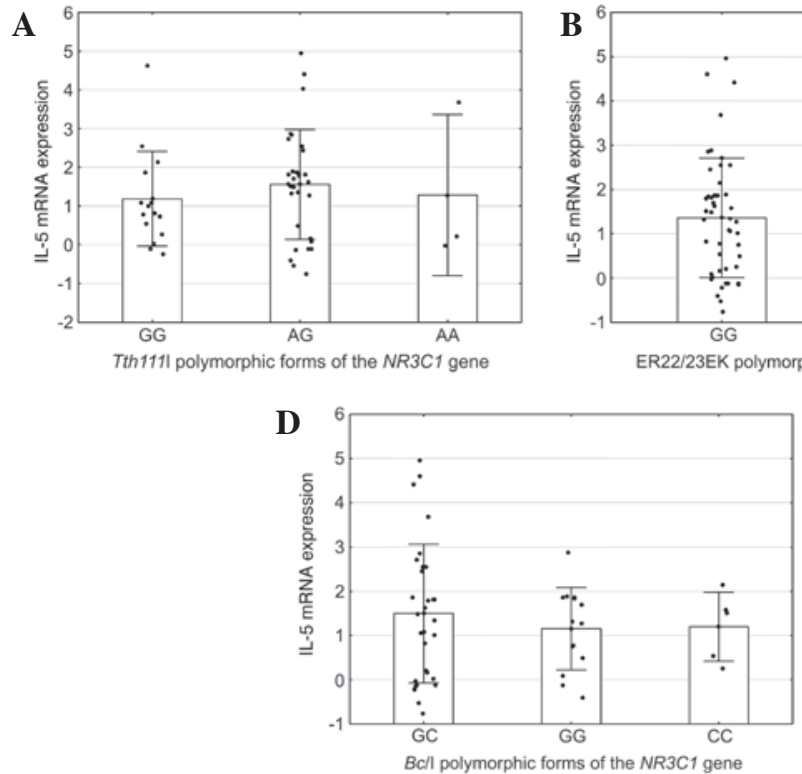
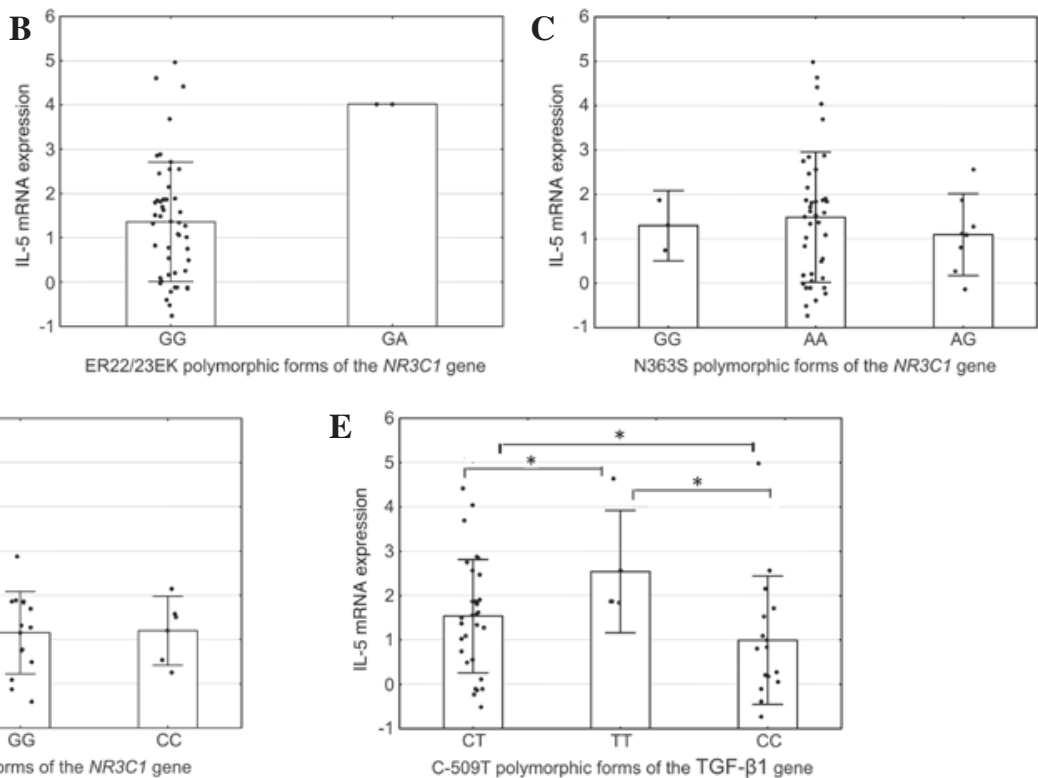

Figure 1. The effect of the NR3C1 gene (A) Tth111I, (B) ER22/23EK, (C) N363S, (D) BclI SNP genotypes and the TGF- 31 gene (E) C-509T SNP genotypes on the IL-5 mRNA expression levels in the control and patient groups. Data are presented as the median and the interquartile range. ${ }^{*}<0.05$. NR3C1, nuclear receptor subfamily 3 , group $\mathrm{C}$, member 1 ; SNP, single nucleotide polymorphism; TGF- $\beta 1$, transforming growth factor $\beta 1$; IL, interleukin.

polymorphic forms, with the most common genotype being AA $(64.44 \%$ controls, $78.46 \%$ asthmatic patients). The least frequently observed genotype, GG (8.89\% controls, $7.69 \%$ asthmatic patients), contributed to a significant increase in the level of IL-15 mRNA expression, by $23 \%$ in the group of patients with asthma. The remaining NR3C1 SNPs did not affect the level of IL-15. The AG heterozygote was the most common form of Tth111I (57.14\% controls, $46.92 \%$ asthmatic patients), and in ER22/23EK was the GG homozygote (94.44\% controls, $96.15 \%$ asthmatic patients). The AA genotype of the ER22/23EK SNP was not observed in either the patient or control group. The most commonly observed genotype in $\mathrm{Bcl}$ was the CG heterozygote $(56.04 \%$ controls, $57.36 \%$ asthmatic patients). None of the TGF- $\beta 1$ SNPs altered the IL-15 
Table V. Frequency of polymorphic forms of $N R 3 C 1$ and TGF- $\beta 1$ SNPs and the effect on IL-15 mRNA expression levels.

\begin{tabular}{|c|c|c|c|c|c|c|c|}
\hline \multirow[b]{2}{*}{ Gene SNP } & \multirow[b]{2}{*}{ Polymorphism } & \multicolumn{2}{|c|}{ Controls } & \multicolumn{2}{|c|}{ Patients } & \multirow[b]{2}{*}{ OR } & \multirow[b]{2}{*}{$95 \% \mathrm{CI}$} \\
\hline & & Frequency & $\begin{array}{l}\text { IL-15 mRNA } \\
\text { expression }\end{array}$ & Frequency & $\begin{array}{l}\text { IL-15 mRNA } \\
\text { expression }\end{array}$ & & \\
\hline \multirow{3}{*}{$\begin{array}{l}\text { Tth111I } \\
\text { (rs10052957) }\end{array}$} & AA & $0.0439,4.40 \%$ & $1.51 \pm 1.84$ & $0.1538,15.38 \%$ & $0.77 \pm 1.03$ & - & - \\
\hline & AG & $0.5715,57.14 \%$ & $0.62 \pm 0.85$ & $0.4692,46.92 \%$ & $0.44 \pm 0.99$ & 0.95 & $0.78-0.11$ \\
\hline & GG & $0.3846,38.46 \%$ & $0.90 \pm 0.94$ & $0.3769,37.69 \%$ & $0.32 \pm 0.94$ & 0.87 & $0.70-1.04$ \\
\hline \multirow{3}{*}{$\begin{array}{l}\text { ER22/23EK } \\
\text { (rs6189/rs6190) }\end{array}$} & $\mathrm{AA}$ & - & - & $0.0000,0.00 \%$ & - & & \\
\hline & $\mathrm{AG}$ & $0.0556,5.56 \%$ & $1.22 \pm 1.31$ & $0.0385,3.85 \%$ & $0.86 \pm 0.67$ & - & - \\
\hline & GG & $0.9444,94.44 \%$ & $0.74 \pm 0.93$ & $0.9615,96.15 \%$ & $0.43 \pm 0.99$ & 0.92 & $0.75-1.09$ \\
\hline \multirow{3}{*}{$\begin{array}{l}\text { N363S } \\
\text { (rs6195) }\end{array}$} & AA & $0.6444,64.44 \%$ & $0.81 \pm 0.94$ & $0.7846,78.46 \%$ & $0.42 \pm 1.00$ & 0.89 & $0.68-1.09$ \\
\hline & $\mathrm{AG}$ & $0.2667,26.67 \%$ & $0.75 \pm 0.97$ & $0.1385,13.85 \%$ & $0.30 \pm 0.76$ & - & - \\
\hline & GG & $0.0889,8.89 \%$ & $0.48 \pm 1.04$ & $0.0769,7.69 \%$ & $1.03 \pm 1.04$ & 1.23 & $1.03-1.44$ \\
\hline \multirow{3}{*}{$\begin{array}{l}\text { BclI } \\
\text { (rs41423247) }\end{array}$} & $\mathrm{CC}$ & $0.0879,8.79 \%$ & $0.37 \pm 0.64$ & $0.1008,10.08 \%$ & $0.05 \pm 0.56$ & - & - \\
\hline & $\mathrm{CG}$ & $0.5604,56.04 \%$ & $0.85 \pm 0.95$ & $0.5736,57.36 \%$ & $0.45 \pm 1.06$ & 1.08 & $0.90-1.25$ \\
\hline & GG & $0.3517,35.16 \%$ & $0.74 \pm 1.00$ & $0.3256,32.56 \%$ & $0.53 \pm 0.92$ & 1.12 & $0.95-1.30$ \\
\hline \multirow{3}{*}{$\begin{array}{l}\text { C-509T } \\
\text { (rs1800469) }\end{array}$} & TT & $0.0805,8.05 \%$ & $0.48 \pm 0.41$ & $0.1102,11.02 \%$ & $0.36 \pm 1.05$ & 0.96 & $0.73-1.20$ \\
\hline & $\mathrm{TC}$ & $0.6322,63.22 \%$ & $0.71 \pm 0.87$ & $0.5669,56.69 \%$ & $0.50 \pm 1.07$ & 1.08 & $0.85-1.32$ \\
\hline & $\mathrm{CC}$ & $0.2873,28.74 \%$ & $1.01 \pm 1.22$ & $0.3228,32.28 \%$ & $0.39 \pm 0.78$ & - & - \\
\hline
\end{tabular}

$N R 3 C 1$, nuclear receptor subfamily 3 , group C, member 1 ; TGF- $\beta 1$, transforming growth factor $\beta 1$; SNPs, single nucleotide polymorphisms; IL, interleukin; OR, odds ratio; CI, confidence interval.
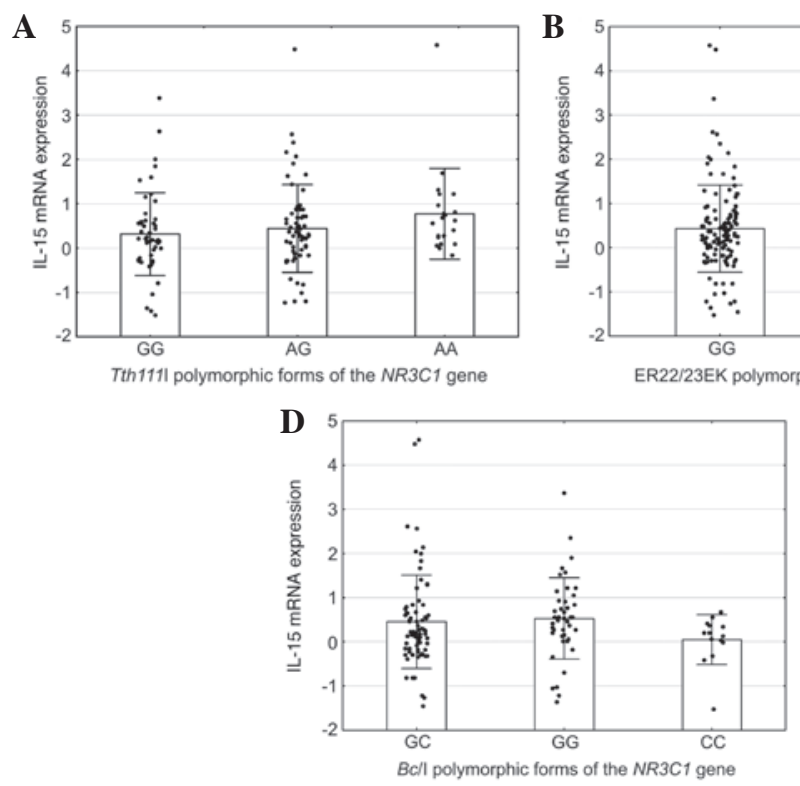
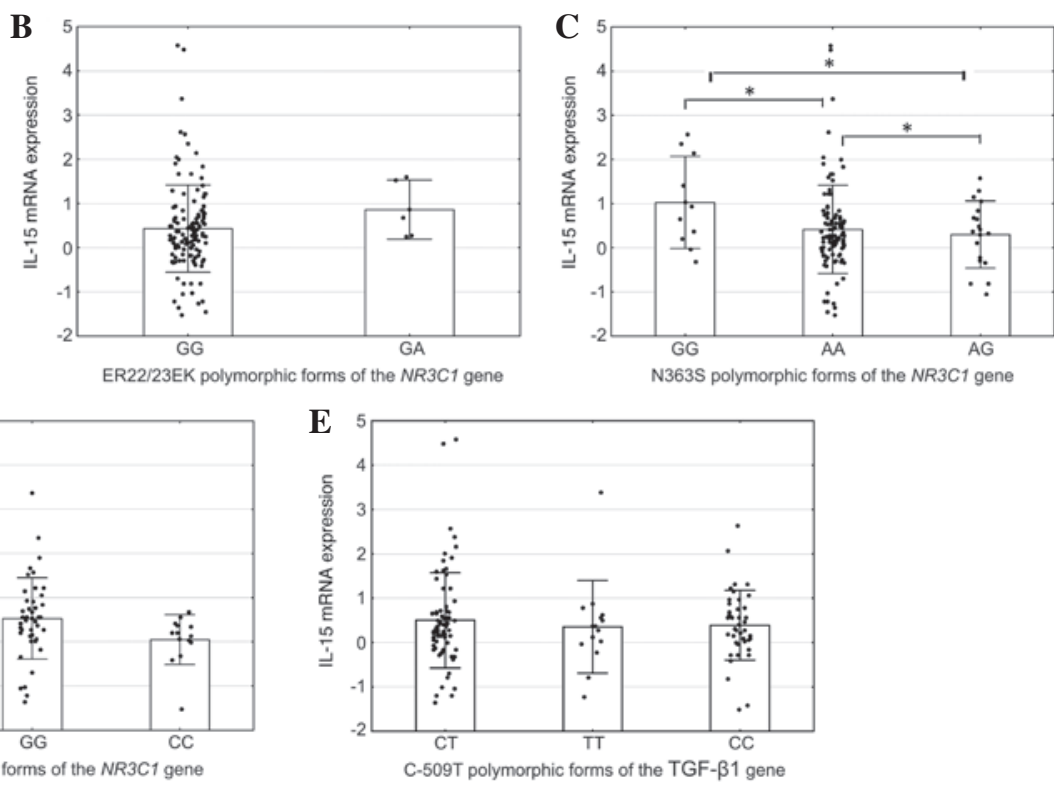

Figure 2. The effect of the NR3C1 gene (A) Tth111I, (B) ER22/23EK, (C) N363S, (D) BclI SNP genotypes and the TGF- 31 gene (E) C-509T SNP genotypes on the IL-15 mRNA expression level in the control and patient groups. Data are presented as the median and the interquartile range. ${ }^{*}<0.05$. NR3C1, nuclear receptor subfamily 3 , group $\mathrm{C}$, member 1 ; SNP, single nucleotide polymorphism; TGF- $\beta 1$, transforming growth factor $\beta 1$; IL, interleukin.

mRNA expression levels. The C-509T SNP occurred in three polymorphic forms, of which the CT heterozygote was the most common (63.22\% controls, $56.69 \%$ asthmatic patients). The remaining two SNPs of the TGF- $\beta 1$ gene, C+466T and $\mathrm{T}+869 \mathrm{C}$, were observed only in the TT homozygote form $(100 \%)$ in the control and patient groups, and no other polymorphic forms, such as CT or CC, were observed. In addition, the TGF- $\beta 1$ SNPs did not affect the IL-15 mRNA expression levels (Table V).

\section{Discussion}

Despite allergy being the predominant cause of asthma, certain genetic factors interacting with environmental determinants 
additionally contribute to the occurrence of the disease. From a clinical perspective, of the genes associated with allergic diseases and asthma, the most important are those which are associated with the function of Th2 lymphocytes, epithelial cells, lung function, bronchial remodeling and the severity of asthma (2). The NR3Cl and TGF- $\beta 1$ genes may be considered to be such genes.

The role of SNPs in the pathogenesis of asthma is currently under investigation, and there are numerous studies on this issue, performed on populations of various types and sizes, however, not all findings are replicable. Notably though, numerous studies have reported the functional role of the NR3C1 and TGF- $\beta 1$ genes in asthma (7,13,15,28,50-52). With regards to basic and clinical studies, it is important to know to what extent these SNPs affect the signaling pathways regulated by the NR3Cl and TGF- $\beta 1$ genes in asthma.

In the present study, the effect of SNPs in the $N R 3 C l$ and TGF- $\beta 1$ genes on interleukin expression was investigated in healthy controls and patients with asthma. The N363S (rs6195) SNP of the NR3C1 gene was observed to have an effect on IL-15 expression, in addition to the C-509T (rs1800469) SNP of the TGF- $\beta 1$ gene which altered IL- 5 expression.

The N363S SNP is localized in exon 2 of the NR3C1 gene. It changes nucleotide sequence AAT to AGT, which results in a conversion of asparagine into serine at codon 363 of the GR (57-59). The N363S results in structural alterations in the $A / B$ region of the GR and functional changes within the AP-1 functional domain, and modulates a number of protein regulation systems (57-59). N363S inhibits the activity of nuclear factor- $\kappa \mathrm{B}$, stimulates the production of inhibitory- $\kappa \mathrm{B}$ and interferes with the suppression of IL-2. In addition, N363S has an influence on the level of GR phosphorylation (57-59). The GR-N363S is characterized with an increased ability to transactivate genes encoding proteins synthesized in cellular response to GCs $(13,50-52)$. The present study indicated that the N363S SNP can additionally regulate IL-15 expression in patients with asthma. The product of the expression of the GG allele of this SNP contributed to a significant increase in IL-15 mRNA level, by $23 \%$. Thus, carriers of the GG genotype of the $\mathrm{N} 363 \mathrm{~S}$ of the $N R 3 C 1$ gene demonstrate a higher risk of inflammation, as regulated by IL-15 in asthma. The decreased frequency of the mutated $\mathrm{G}$ allele in the asthmatic patient group (controls $\mathrm{GG}=8.89 \%$ compared with patients $\mathrm{GG}=7.69 \%$ ) correlated with a reduced response to GC therapy and elevated level of IL-15 mRNA. In vivo studies have indicated that the N363S SNP is associated with an increased sensitivity to GCs (57). In the present study, it was noted that the carriers of the N363S SNP appeared to be clinically healthy and more sensitive to treatment with exogenous GCs. In a previous study, an increased frequency of the occurrence of the A allele at the cost of the G polymorphic allele in the analyzed N363S SNP was statistically correlated with a higher incidence of a more severe form of asthma and the inability to reduce its symptoms with the administration of anti-inflammatory drugs (60). This is a potential mechanism which may account for the increase observed in IL-15 expression in the patients with asthma treated with GCs (60).

The C-509T (allele C/T) SNP, located in the promoter of the TGF- $\beta 1$ gene, serves a crucial role as it increases the expression of TGF- $\beta 1$ and IgE. Thus, it is an important factor associated with bronchial remodeling and the development of asthma $(46,47)$. The C-509T SNP is a regulator of the expression of TGF- $\beta 1$, and carriers of this SNP have been reported to exhibit increased expression of TGF- $\beta 1$, which, in eosinophils, acts as a negative regulator of eosinophil survival (36). Eosinophils are destroyed by apoptosis when the levels of eosinophil-activating cytokines, such as granulocyte-macrophage colony-stimulating factor and IL-5, are insufficient. TGF- $\beta 1$ blocks the activity of IL-5, which is unable to prevent apoptosis of eosinophils (36). However, increased expression of TGF- $\beta 1$ and increased eosinophil accumulation are observed in sites of allergic inflammation in patients with asthma; in addition, eosinophils themselves can produce TGF- $\beta 1$ (36). These paradoxical observations suggest that eosinophils may have aberrant TGF-signaling, resulting in partial or complete TGF-resistance (36). In the present study, by increasing TGF- $\beta 1$, the C-509T SNP contributed to an increase in IL-5 expression and exacerbation of the inflammation in the bronchi of patients with asthma. The product of the two TT alleles appeared to increase the risk of IL-5-induced inflammation by $44 \%$. With regards to the remaining TGF- $\beta 1$ SNPs, the present study did not indicate any correlation between the gene and IL-15 expression. In order to confirm these results, it studies investigating the expression of TGF/Smad signaling pathway will be required, in particular to determine Smad2/3 and Smad4 levels, as these cytokines serve a crucial role in stimulating the synthesis of fibronectin, proteoglycans and type I and III collagen. In addition, these cytokines increase eosinophil chemotaxis following allergen exposure in the bronchi of patients with asthma.

The present study indicated associations, however, further studies are required based on functional models of the investigated proteins. Clinical observations based on the observations of the present study require further experimental studies to confirm these phenomena.

The present study is the first, to the best of our knowledge, to analyze the functional impact of NR3C1 and TGF- $\beta 1$ SNPs on interleukin expression in patients with asthma. A correlation between the C-509T SNP of the TGF- $\beta 1$ gene and IL-5 mRNA expression was demonstrated, in addition to a correlation between the N363S SNP of the NR3C1 gene and IL-15 expression. This observation is important because IL-5 has an influence on the level of eosinophils, bronchial hyperreactivity and obstruction in addition to the clinical symptoms of asthma. IL-15 is an important regulator of the immune response in this disease.

The current study provides the clinical basis for performing the genetic screening of patients. This may enable the implementation of methods to prevent asthma development in particular patient groups (such as asthma endotype). Thus, the early identification of patients demonstrating a risk of more severe course of asthma (carriers of certain SNPs) will be possible, in addition to the introduction of an intensive anti-inflammatory therapy (GCs) earlier, which may prevent disease progression, exacerbations and bronchial remodeling.

\section{Acknowledgements}

The authors would like to thank Ms. Joanna Molinska, MA for assistance with administration and Ms. Beata 
Małachowska, MD for assistance with statistical analysis. Ms. Beata Małachowska was supported by the TEAM project financed by the Innovative Economy Operational Program and coordinated by the Foundation for Polish Science. The authors would like to thank Mr. Grzegorz Uraziński, MSc Eng, for the preparation of the figures and assistance in graphic rendering of research materials. The authors would additionally like to thank all those who provided assistance during the completion of the study. The present study was funded by a grant from the Clinic of Internal Medicine, Asthma and Allergies, II Chair of Internal Medicine, Medical University of Lodz, Poland (grant no. 503/1-095-03/503-01).

\section{References}

1. Gajewski P, Mejza F and Niżankowska-Mogilnicka E: Rozpoznanie i leczenie astmy u dorosłych. Podsumowanie wytycznych GINA 2014. Med Prakt 9, 2014 (In Polish).

2. Fal A (ed): Alergia, Choroby Alergiczne, Astma. Medycyna Praktyczna, Kraków, 2010 (In Polish).

3. Greenfeder S, Umland SP, Cuss FM, Chapman RW and Egan RW: Th2 cytokines and asthma. The role of interleukin-5 in allergic eosinophilic disease. Respir Res 2: 71-79, 2001.

4. Holgate ST: Pathogenesis of asthma. Clin Exp Allergy 38: 872-897, 2008

5. Broide DH: Immunologic and inflammatory mechanisms that drive asthma progression to remodeling. J Allergy Clin Immunol 121: 560-570, 2008.

6. Torrego A, Hew M, Oates T, Sukkar M and Fan Chung K: Expression and activation of TGF-beta isoforms in acute allergen-induced remodelling in asthma. Thorax 62: 307-313, 2007.

7. Panek M, Pietras T, Fabijan A, Zioło J, Wieteska, $€$ Małachowska B, Fendler W, Szemraj J and Kuna P: The NR3C1 glucocorticoid receptor gene polymorphisms may modulate the TGF-beta mRNA expression in asthma patients. Inflammation 38: 1479-1492, 2015

8. Ito K, Chung KF and Adcock IM: Update on glucocorticoid action and resistance. J Allergy Clin Immunol 117: 522-543, 2006.

9. Leung DY and Bloom JW: Update on glucocorticoid action and resistance. J Allergy Clin Immunol 111: 3-22, 2003.

10. Kino T, De Martino MU, Charmandari E, Mirani M and Chrousos GP: Tissue glucocorticoid resistance/hypersensitivity syndromes. J Steroid Biochem Mol Biol 85: 457-467, 2003.

11. Nicolaides NC, Galata Z, Kino T, Chrousos GP and Charmandari E: The human glucocorticoid receptor: Molecular basis of biologic function. Steroids 75: 1-12, 2010 .

12. Hawkins GA, Amelung PJ, Smith RS, Jongepier H, Howard TD, Koppelman GH, Meyers DA, Bleecker ER and Postma DS Identification of polymorphisms in the human glucocorticoid receptor gene (NR3C1) in a multi-racial asthma case and control screening panel. DNA Seq 15: 167-173, 2004.

13. Panek M, Pietras T, Fabijan A, Miłanowski M, Wieteska L, Górski P, Kuna P and Szemraj J: Effect of glucocorticoid receptor gene polymorphisms on asthma phenotypes. Exp Ther Med 5: $572-580,2013$

14. de Lange P, Koper JW, Huizenga NA, Brinkmann AO, de Jong FH, Karl M, Chrousos GP and Lamberts SW: Differential hormone-dependent transcriptional activation and -repression by naturally occurring human glucocorticoid receptor variants. Mol Endocrinol 11: 1156-1164, 1997.

15. Pietras T, Panek M, Tworek D, Oszajca K, Wujcik R, Górski P, Kuna P and Szemraj J: The BclI single nucleotide polymorphism of the human glucocorticoid receptor gene h-GR/NR3C1 promoter in patients with bronchial asthma: Pilot study. Mol Biol Rep 38: 3953-3958, 2011.

16. Grzanka A and Jarzab J: Nongenomic effects of glucocorticoids. Pneumonol Alergol Pol 77: 387-393, 2009 (In Polish).

17. Barnes P: Molecular mechanisms of glucocorticoid action in asthma. Pulm Pharmacol Ther 10: 3-19, 1997.

18. Barnes P: Glucocorticosteroids. In: Asthma: Basic Mechanisms and Clinical Management. Barnes P, Rodger I, Thompson N (eds). 3rd Edition. Academic Press, Cambridge, MA. pp725-766, 1998.
19. Newton R, Barnes $\mathrm{P}$ and Adcock I: Transcription Factors. In: Asthma: Basic Mechanisms and Clinical Management. Barnes P, Rodger I, Thompson N (eds). 3rd Edition. Academic Press, Cambridge, MA. pp459-474, 1998.

20. Komai-Koma M, McKay A, Thomson L, McSharry C, Chalmers GW, Liew FY and Thomson NC: Immuno-regulatory cytokines in asthma: IL-15 and IL-13 in induced sputum. Clin Exp Allergy 31: 1441-1448, 2001.

21. Arai KI, Lee F, Miyajima A, Miyatake S, Arai N and Yokota T: Cytokines: Coordinators of immune and inflammatory responses. Annu Rev Biochem 59: 783-836, 1990.

22. Bousquet J, Chanez P, Lacoste JY, Barnéon G, Ghavanian N, Enander I, Venge P, Ahlstedt S, Simony-Lafontaine J and Godard P: Eosinophilic inflammation in asthma. N Engl J Med 323: 1033-1039, 1990.

23. Coyle AJ, Ackerman SJ and Irvin CG: Cationic proteins induce airway hyperresponsiveness dependent on charge interactions. Am Rev Respir Dis 147: 896-900, 1993.

24. Tomasiak-Łozowska MM, Bodzenta-Łukaszyk A, Tomasiak M, Skiepko R and Zietkowski Z: The role of interleukin 13 and interleukin 5 in astma. Postepy Hig Med Dosw (Online) 64: 146-155, 2010.

25. Bierbaum S, Nickel R, Zitnik S, Ahlert I, Lau S, Deichmann KA Wahn U and Heinzmann A: Confirmation of association of IL-15 with pediatric asthma and comparison of different controls. Allergy 61: 576-580, 2006.

26. Jachnik M, Szczepankiewicz A and Bręborowicz A: Influence of IL15 gene polymorphism on the course of bronchial asthma in children. Alergia Astma Immunologia 16: 200-204, 2011.

27. Letterio JJ and Roberts AB: TGF-beta: A critical modulator of immune cell function. Clin Immunol Immunopathol 84: 244-250, 1997.

28. Panek M, Pietras T, Szemraj J, Fabijan A and Kuna P: Identification and association of TGF $\beta-1$ expression in patients with asthma in a Polish population-Lodz metropolitan area study. Int J Biochem Mol Biol 4: 67-74, 2013.

29. Ten Dijke P, GeurtsVanKessel AH, Foulkes JG and Le Beau MM: Transforming growth factor type beta 3 maps to human chromosome 14, Region q23-q24. Oncogene 3: 721-724, 1988.

30. Wahl SM: Transforming growth factor-beta: Innately bipolar. Curr Opin Immunol 19: 55-62, 2007.

31. Bottoms SE, Howell JE, Reinhardt AK, Evans IC and McAnulty RJ: Tgf-beta isoform specific regulation of airway inflammation and remodelling in a murine model of asthma. PLoS One 5: e9674, 2010.

32. Bossé Y, Stankova J and Rola-Pleszczynski M: Transforming growth factor-betal in asthmatic airway smooth muscle enlargement: Is fibroblast growth factor-2 required? Clin Exp Allergy 40: 710-724, 2010.

33. Xie Q, Shen ZJ, Oh J, Chu H and Malter JS: Transforming growth factor- $\beta 1$ antagonizes interleukin-5 pro-survival signaling by activating calpain-1 in primary human eosinophils. J Clin Cell Immunol Suppl 1: 2011

34. Pardali K and Moustakas A: Actions of TGF-beta as tumor suppressor and pro-metastatic factor in human cancer. Biochim Biophys Acta 1775: 21-62, 2007.

35. Shen ZJ, Esnault S, Rosenthal LA, Szakaly RJ, Sorkness RL, Westmark PR, Sandor M and Malter JS: Pin1 regulates TGF-beta1 production by activated human and murine eosinophils and contributes to allergic lung fibrosis. J Clin Invest 118: 479-490, 2008.

36. Kanzaki M, Shibagaki N, Hatsushika K, Mitsui H, Inozume T, Okamoto A, Dobashi Y, Ogawa H, Shimada S and Nakao A: Human eosinophils have an intact Smad signaling pathway leading to a major transforming growth factor-beta target gene expression. Int Arch Allergy Immunol 142: 309-317, 2007.

37. Alam R, Forsythe P, Stafford S and Fukuda Y: Transforming growth factor beta abrogates the effects of hematopoietins on eosinophils and induces their apoptosis. J Exp Med 179: 1041-1045, 1994.

38. Pazdrak K, Justement L and Alam R: Mechanism of inhibition of eosinophil activation by transforming growth factor-beta. Inhibition of Lyn, MAP, Jak2 kinases and STAT1 nuclear factor. J Immunol 155: 4454-4458, 1995.

39. Goplen N, Gorska MM, Stafford SJ, Rozario S, Guo L, Liang Q and Alam R: A phosphosite screen identifies autocrine TGF-beta-driven activation of protein kinase $\mathrm{R}$ as a survival-limiting factor for eosinophils. J Immunol 180: 4256-4264, 2008. 
40. Zhao J, Li P and Gao S: Effect of TGF-betal on the expression of IL-12, IL-15, IL-18, IL-4 and IL-10 in heart transplantation rejection in rats. J Huazhong Univ Sci Technolog Med Sci 27: 643-645, 2007.

41. Godoy P, Weng HL, Bachmann A, Bulanova E, Bulfone-Paus S and Dooley S: Interleukin-15 expression is induced by TGF-beta in hepatocytes: A new role for IL-15 in liver disease? Z Gastroenterol 46: 243, 2009.

42. Mak JC, Leung HC, Ho SP, Law BK, Ho AS, Lam WK, Ip MS and Chan-Yeung MM: Analysis of TGF-beta (1) gene polymorphisms in Hong Kong Chinese patients with asthma. J Allergy Clin Immunol 117: 92-96, 2006.

43. Grainger DJ, Heathcote K, Chiano M, Snieder H, Kemp PR, Metcalfe JC, Carter ND and Spector TD: Genetic control of the circulating concentration of transforming growth factor type beta1. Hum Mol Genet 8: 93-97, 1999.

44. Hobbs K, Negri J, Klinnert M, Rosenwasser LJ and Borish L: Interleukin-10 and transforming growth factor-beta promoter polymorphisms in allergies and asthma. Am J Respir Crit Care Med 158: 1958-1962, 1998.

45. Pulleyn LJ, Newton R, Adcock IM and Barnes PJ: TGFbeta1 allele association with asthma severity. Hum Genet 109 623-627, 2001.

46. Silverman ES, Palmer LJ, Subramaniam V, Hallock A, Mathew S, Vallone J, Faffe DS, Shikanai T, Raby BA, Weiss ST and Shore SA: Transforming growth factor-beta1 promoter polymorphism C-509T is associated with asthma. Am J Respir Crit Care Med 169: 214-219, 2004.

47. Nagpal K, Sharma S, B-Rao C, Nahid S, Niphadkar PV, Sharma SK and Ghosh B: TGFbeta1 haplotypes and asthma in Indian populations. J Allergy Clin Immunol 115: 527-533, 2005.

48. Buckova D, IzakovicováHollá, L, Benes P, Znojil V and Vácha J: TGF-beta1 gene polymorphisms. Allergy 56: 1236-1237, 2001.

49. Miller MR, Hankinson J, Brusasco V, Burgos F, Casaburi R, Coates A, Crapo R, Enright P, van der Grinten CP, Gustafsson $\mathrm{P}$, et al: Standardisation of spirometry. Eur Respir J 26: 319-338, 2005.

50. Pietras T, Panek M, Kuprys-Lipinska I, Oszajca K, Wujcik R, Kuna P, Gorski P and Szemraj J: Frequencies of BclI, E22E, and N363S of h-GR/NR3C1 restriction fragment length polymorphisms of glucocorticoid receptor gene in Polish adult population. Med Sci Monit 16: CR475-CR479, 2010.
51. Panek M, Pietras T, Antczak A, Fabijan A, Przemecka M, Górski P, Kuna P and Szemraj J: The N363S and I559N single nucleotide polymorphisms of the $\mathrm{h}-\mathrm{GR} / \mathrm{NR} 3 \mathrm{C} 1$ gene in patients with bronchial asthma. Int J Mol Med 30: 142-150, 2012.

52. Panek M,Pietras T, Antczak A, Górski P, Kuna P and Szemraj J: The role of functional single nucleotide polymorphisms of the human glucocorticoid receptor gene NR3C1 in Polish patients with bronchial asthma. Mol Biol Rep 39: 4749-4757, 2012.

53. Panek M, Pietras T, Fabijan A, Zioło J, Wieteska L, Małachowska B, Fendler W, Szemraj J and Kuna P: Identification and association of the single nucleotide polymorphisms, C-509T, C+466T and T+869C , of the TGF- $\beta 1$ gene in patients with asthma and their influence on the mRNA expression level of TGF- $\beta 1$. Int J Mol Med 34: 975-986, 2014

54. Chomczynski P and Sacchi N: Single-step method of RNA isolation by acid guanidinium thiocyanate-phenol-chloroform extraction. Anal Biochem 162: 156-159, 1987.

55. Winer J, Jung CK, Shackel I and Williams PM: Development and validation of real-time quantitative reverse transcriptase-polymerase chain reaction for monitoring gene expression in cardiac myocytes in vitro. Anal Biochem 270: 41-49, 1999.

56. Livak KJ and Schmittgen TD: Analysis of relative gene expression data using real-time quantitative PCR and the 2 (-Delta Delta C(T)) method. Methods 25: 402-408, 2001.

57. DeRijk R, Schaaf M and de Kloet E: Glucocorticoid receptor variants: Clinical implications. J Steroid Biochem Mol Biol 81: 103-122, 2002.

58. Szabó V, Borgulya G, Filkorn T, Majnik J, Bányász I and Nagy ZZ: The variant N363S of glucocorticoid receptor in steroid-induced ocular hypertension in Hungarian patients treated with photorefractive keratectomy. Mol Vis 13: 659-666, 2007.

59. Majnik J, Patócs A, Balogh K, Tóth M and Rácz K: A rapid and simple method for detection of Asn363Ser polymorphism of the human glucocorticoid receptor gene. J Steroid Biochem Mol Biol 92: 465-468, 2004

60. Huizenga NA, Koper JW, De Lange P, Pols HA, Stolk RP, Burger H, Grobbee DE, Brinkmann AO, De Jong FH and Lamberts SW: A polymorphism in the glucocorticoid receptor gene may be associated with and increased sensitivity to glucocorticoids in vivo. J Clin Endocrinol Metab 83: 144-151, 1998. 